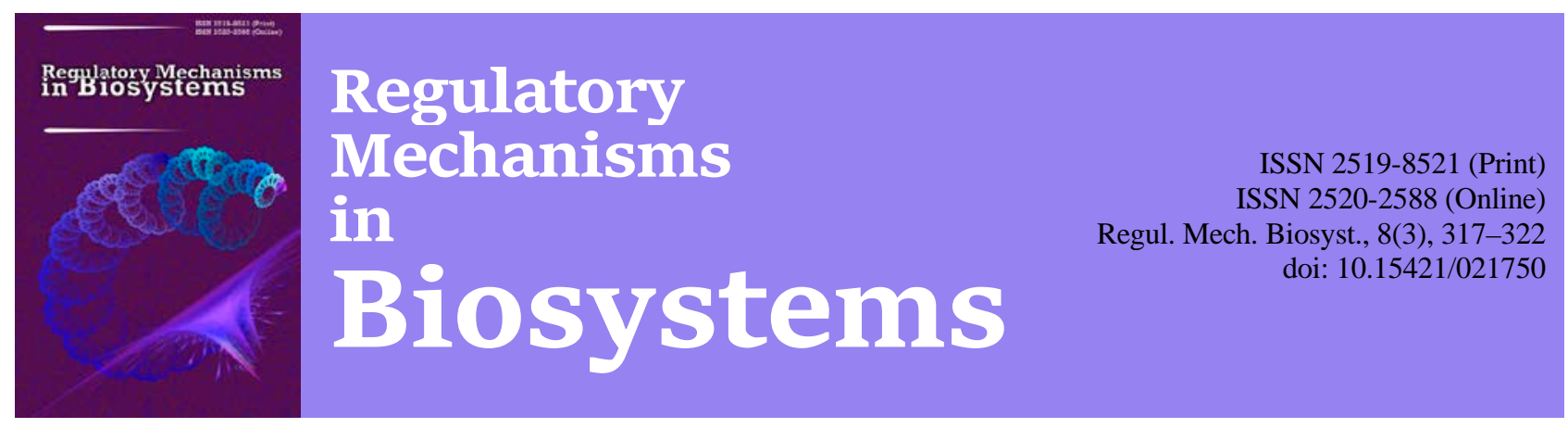

\title{
The impact of growth stimulators and retardants on the utilization of reserve lipids by sunflower seedlings
}

\author{
V. G. Kuryata, I. V. Poprotska, T. I. Rogach \\ Vinnytsya State Pedagogical University named after Mykhailo Kotsyubynsky, Vinnytsya
}

Article info

Received 24.05.2017

Received in revised form 23.06.2017

Accepted 28.06.2017

Vinnytsya State Pedagogical University named after Mykhailo Kotsyubynsky, Ostrozhskogo Str., 32

Vinnytsya, 21000, Ukraine.

Tel.: +38-067-261-98-97.

E-mail: i_poprotska@ukr.net
Kuryata, V. G., Poprotska, I. V., \& Rogach, T. I. (2017). The impact of growth stimulators and retardants on the utilization of reserve lipids by sunflower seedlings. Regulatory Mechanisms in Biosystems, 8(3), 317-322. doi: 10.15421/021750

Using growth stimulators and anti-gibberillin preparations of different chemical compounds, we created different pressures in the coordinate covalent bond systems during germination of sunflower seeds. Using gibberellin and treptolem growth stimulators and Paclobutrazol and Chlormequat-Chlorid anti-gibberillin preparations is an efficient method of reconstructing coordinate covalent bond during the germination of seeds of oil-bearing crops. It allows determination of the role of the hormone factor in the utilization of reserve lipids over the heterotrophic phase of plant development. Blocking the synthesis of gibberellins by retardants caused decrease in activity of lipase, hydrolysis of reserve lipids and the meristem, which resulted in decrease in the energy of germination. Compared to the control, the impact of gibberellin increased the content of butyric acid, and the impact of Paclobutrazol reduced the content of butyric acid. Linoleic acid showed exactly the opposite changes. In relation to the control, a significant increase in the content of non-saturated linoleic acid was observed in both variants of the experiment. Gibberellic acid stimulated and Paclobutrazol slowed the usage of free higher fatty acids for the process of morphogenesis.

Keywords: Helianthus annuus L.; "source-sink” relations; retardants; hormonal regulation; germination of seeds

\section{Вплив стимуляторів росту та ретардантів на утилізацію резервної олії проростками соняшнику}

\author{
В. Г. Кур'ята, I. В. Попроцька, Т. І. Рогач
}

Вінницький державний педагогічний університет імені Михайла Коичюбинського, Вінниия, Украӥна

Створювали різне напруження в системі «донор - акцептор» у процесі проростання насіння соняшнику, використовуючи стимулятори росту та антигіберелінові препарати різної хімічної будови. Застосування стимуляторів росту гібереліну та трептолему та антигіберелінових препаратів паклобутразолу та хлормекватхлориду - ефективний прийом реконструкції донорно-акцепторних відносин у період проростання насіння олійних культур, що дозволяє встановити роль гормонального фактори в утилізації резервних ліпідів у гетеротрофну фазу розвитку рослини. Блокування синтезу гіберелінів ретардантами спричинило зниження активності ліпаз, гідролізу резервної олії, зниження активності меристем і відповідне зниження енергії проростання насіння. За дії гібереліну зростав, а за дії паклобутразолу зменшувався вміст олеїнової кислоти проти контролю, протилежні зміни відмічено для лінолевої кислоти. Суттєве зростання вмісту ненасиченої ліноленової кислоти відбувалося в обох варіантах досліду порівняно з контролем. Гіберелова кислота стимулювала, а ретардант паклобутразол уповільнював використання вільних вищих жирних кислот на процеси морфогенезу.

Ключові слова: Helianthus annuиs L.; донорно-акцепторні відносини; ретарданти; гормональна регуляція; проростання насіння

Вступ

Розроблення способів регуляції донорно-акцепторної системи (система «source - sink») рослин має суттєве теоретичне та практичне значення, оскільки відкриває перспективи спрямованого перерозподілу потоків асимілятів до господарсько-цінних органів рослини. Нині у продукційному процесі рослин найкраще вивчені питання функціональної та регуляторної взаємодії фотосинтезу та pосту (Kuryata, 2009; Kiriziy et al., 2014). Відповідно до сучасних уявлень вища рослина являє собою цілісну систему, де донор асимілятів - фотосинтетичні органи, перш за все листки, а інші частини рослини виступають як акцептор. Основні закономірності фун- кціонування донорно-акцепторних відносин вивчають, в основному, під час аналізу співвідношення інтенсивності процесів росту та фотосинтезу, де процеси росту виступають як основний акцептор, а фотосинтез - як донор асимілятів (Kuryata and Polyvanyj, 2015; Rogach and Rogach, 2015; Yu et al., 2015; Kuryata et al., 2016; Rogach et al., 2016). Під асимілятами при цьому мають на увазі різні сполуки, асимільовані рослиною у процесі фотосинтезу вуглецю, у першу чергу транспортні та запасні форми вуглеводів основу енергетичних і метаболічних процесів, а також «будівельний матеріал» у процесах росту та розвитку на всіх рівнях організації рослинного організму (Kiriziy et al., 2014). Виділяють три типи атрагувальних центрів, які відрізняються характером функ- 
ціональної активності: точки росту, місця відкладання речовин у запас та місця активного метаболізму, причому встановлено, що існує позитивна кореляція між кількістю та активністю цих акцепторів і фотосинтезувальною активністю листків. Регуляція цих відносин як системи перерозподілу асимілятів між органами та тканинами рослини в онтогенезі може здійснюватися на всіх рівнях організації за участі різних механізмів (Mohammad and Mohammad, 2013; Ljung et al., 2015; Savage et al., 2015; Sugiura et al., 2015; Bonelli et al., 2016).

У практичному плані для оптимізації ростових процесів і продуктивності рослин застосовують синтетичні регулятори росту, в тому числі ретарданти (Ramburan and Greenfield, 2007; Kumar et al., 2012; Tae-Yun and Jung-Hee, 2012; Pavlista, 2013; Yan et al., 2013; Sang-Kuk and Hak-Yoon, 2014; Sardoei et al., 2014; Yan et al., 2015; Panyapruek et al., 2016; Wang et al., 2016). Разом із цим, значно менше інформації про функціонування цієї системи в гетеротрофну фазу розвитку рослини (період проростання насіння, бульб, кореневищ, цибулин). У цей період відбувається використання на потреби морфогенезу депонованих в органах запасання резервних сполук різної хімічної будови (вуглеводів, азотумісних сполук і оліі). Існуюча інформація свідчить про можливість регуляції швидкості утилізації резервних сполук на потреби росту та розвитку зовнішніми та внутрішніми чинниками.

Швидкість росту стебла залежить від меристематичної активності субапікальної зони, яка значною мірою контролюється гіберелінами (Minguet et al., 2014; Hedden and Thomas, 2016). Фотоморфогенез (розвиток на світлі) та скотоморфогенез (розвиток у темряві) потребують різного рівня забезпечення пластичними речовинами (Golovatskaya and Karnachuk, 2007; Kutschera and Briggs, 2013; Wu, 2014; Franklin, 2016; Poprotska and Kuryata, 2017). Посилення ростової функції паростками картоплі у темряві супроводжується підвищенням активності амілази та інтенсивнішим використанням запасного крохмалю бульб (Rogach et al., 2016). Серед внутрішніх факторів регуляції напруження донорно-акцепторних відносин ключову роль відіграє гормональна система. Фітогормони включені в систему трансдукції світлового сигналу (Hornitschek et al., 2012; Zhang et al., 2014; Humplík et al., 2015; De Wit and Pierik, 2016; Van Hook, 2016). Зокрема, за дії світла змінюється метаболізм і чутливість рослин до гіберелінів (Zhang et al., 2014). Проростання насіння та органів запасання, які містять як основну резервну речовину крохмаль, супроводжується ініційованим гібереліном синтезом de novo та виділенням зародком в ендосперм чотирьох ізоферментів $\alpha$-амілази, що викликає розщеплення крохмалю у крохмальних зернах. Застосування екзогенного гібереліну також спричиняє посилення цих процесів та стимуляцію росту проростка. 3 іншого боку, застосування інгібіторів росту - ретардантів, які за механізмом дії - антигібереліни, дозволяє зменшити «запит» на асиміляти внаслідок блокування синтезу гіберелінів, активності амілазного комплексу та зниження інтенсивності функціонування меристем.

Четвертинні амонієві, фосфонієві та сульфонієві солі (АМО 1618, ССС, ДХІБ, фосфон D) переривають біосинтез гіберелінів в одній ланці цього процесу, а основа сильнішої рістгальмівної дії триазолпохідних ретардантів (паклобутразолу, уніконазолу, BAS 111 тощо) - блокування ферментів синтезу гіберелінів на трьох етапах. Ці дані підтверджуються тим, що ретардантні ефекти дії четвертинних та триазолових сполук усуваються введенням екзогенної гіберелової кислоти (Kuryata, 2009). Таким чином, з’являється можливість, використовуючи під час проростання насіння екзогенний стимулятор росту (гіберелін або ретардант), змінювати напруженість донорно-акцепторних відносин у рослині шляхом стимулювання або інгібування інтенсивності росту проростка. Зокрема, вивчення впливу гібереліну та антигіберелінового препарату хлормекватхлориду на газообмін та використання резервних сполук у проростків гарбуза у процесі проростання на світлі та у темряві показало, що за умов скотоморфогенезу у проростків гарбуза посилення або гальмування росту спричинило підвищення інтенсивності дихання. У випадку перемикання типу живлення на світлі з гетеротрофного на автотрофний обробка гібереліном збільшувала частку асиміляційних процесів у вуглекислотному газообміні проростків, а гальмування росту ретардантом спричинювало збільшення дихальних витрат.

Формування проростками «запиту» на резервні асиміляти 3 сім'ядоль великою мірою визначається зміною активності субапікальних меристем, що проявляється у прискоренні проростання насіння, посиленні гістогенезу за дії гібереліну та послаблення цих процесів за впливу ретарданту (Poprotska and Kuryata, 2017).

Швидкість росту стебла залежить від меристематичної активності субапікальної зони, яка значною мірою контролюється гіберелінами. Встановлено тісний зв'язок між змінами ростових характеристик за дії ретардантів і активністю гормону: за впливу паклобутразолу, хлормекватхлориду та декстрелу відмічено зменшення активності вільних гіберелінів у пагонах малини в умовах вегетаційного та польового дослідів, у той час як уведення екзогенної гіберелової кислоти суттєво підвищувало їх активність у тканинах стебла. Разом із цим, зводити ростову реакцію рослин лише до вмісту та активності гіберелінів було б, на нашу думку, неправильним, оскільки вирішальну роль відіграє баланс, співвідношення та послідовність дії різних груп фітогормонів.

Застосування різних груп ретардантів за гальмування росту пагонів малини суттєво зменшило вміст вільної індолілоцтової кислоти (Kuryata, 2009). Відмічалися також зміни у співвідношенні зеатинрибозиду та зеатину за дії паклобутразолу у бік менш активної, транспортної форми гормону (зеатинрибозиду). Застосування хлормекватхлориду та паклобутразолу впливало не лише на активність фітогормонів - стимуляторів росту, а і на вміст абсцизової кислоти (АБК) у пагонах рослин - зростав уміст вільної форми фітогормону. При цьому застосування етиленпродуцента декстрелу, який не впливає на синтез гібереліну, а блокує активність уже синтезованого гормону, значно менше впливало на вміст АБК. Збілышення вмісту АБК у тканинах рослин у період активного росту за дії хлормекватхлориду та паклобутразолу за одночасного зменшення вмісту гіберелінів пояснюється тим, що синтез абсцизової кислоти та гіберелінів - гілки єдиного шляху утворення терпенів, і в обох випадках їх синтез іде через мевалонову кислоту. У метаболізмі рослини існує метаболічне розгалуження, на кінцях якого утворюються гібереліни та абсцизова кислота. У цих умовах застосування ретардантів спричиняє зміщення синтезу терпенів у бік синтезу сексвітерпенів - АБК. Такі зміни у синтезі гормонального комплексу у період проростання викликають відповідні зміни співвідношення стимулятори / інгібітори росту та гальмування ростових процесів. При цьому порівняльний вплив стимуляторів росту та ретардантів на ріст проростків і особливості використання резервної олії насіння олійних культур під час проростання, на відміну від насіння злакових, які містять резервний крохмаль, вивчено недостатньо.

У зв'язку із цим, мета цієї статті - встановити особливості використання резервних ліпідів насіння соняшнику під час моделювання різного напруження донорно-акцепторних відносин за впливу стимуляторів росту гіберелової кислоти та трептолему та інгібіторів росту хлормекватхлориду та паклобутразолу.

\section{Матеріал і методи досліджень}

Для впливу на інтенсивність проростання насіння соняшнику в різних варіантах досліду застосовували обробку стимуляторами росту гібереловою кислотою $\left(Г К_{3}\right)$ і трептолемом, а також інгібіторами росту хлормекватхлоридом (ССC) і паклобутразолом $\left(\mathrm{P}_{333}\right)$. У статті описано такі препарати (Grytsayenko et al., 2008; Kuryata, 2009).

Гіберелова кислота $\left(\mathrm{C}_{19} \mathrm{H}_{22} \mathrm{O}_{6}\right)$ - біла кристалічна речовина 3 молекулярною масою 346,2 Да. Температура плавлення $227^{\circ} \mathrm{C}$. Речовина погано розчинна у воді та добре розчинна в органічних розчинниках. Гіберелова кислота малотоксична сполука, належить до 3-го класу токсичності. ЛД 50 для щурів 15630 мг/кг.

Трептолем - комплексний препарат 2,6-диметилпіридин-1оксиду з бурштиновою кислотою (50 г/л) та Емістиму С (1 г/л). 
До препарату у складі Емістиму С входять також фітогормони гіберелінової, ауксинової, цитокінінової природи, амінокислоти, вуглеводи, мікроелементи, отримані шляхом культивування грибів - ендофітів із кореневої системи рослин на штучному живильному середовищі.

Хлормекватхлорид ( $\beta$-хлоретилтриметиламонійхлорид) похідна четвертинних амонієвих солей. Це біла кристалічна речовина, молекулярна маса - 158,1 Да, температура розкладання $-300{ }^{\circ} \mathrm{C}$, розчинність у воді $-74 \%$ при $20^{\circ} \mathrm{C}$. Добре розчиняється у спиртах, ацетоні та погано у вуглеводнях. ЛД 50 для білих пацюків - 600-700 мг/кг, малотоксичний для риб. Препарат малотоксичний, не виявляє канцерогенних і бластомогенних властивостей, не акумулюється і не розкладається в організмі, через 48 годин виводиться з нього. Період напіврозпаду у грунті, залежно від температури та вологості грунту, становить 3-48 діб. Паклобутразол $\left(\mathrm{P}_{333}\right)$ - 4,4-диметил-1-(1,2,4триазоліл-1)-1-(4-хлорфеніл)пентанол-3, похідна 1,2,4-триазолу. Характеризується низькою розчинністю у воді - 0,035 г/л, температура плавлення $165-166^{\circ} \mathrm{C}$. ЛД 50 для білих пацюків 13561953 мг/кг. Висока активність паклобутразолу пов’язана зі стабільністю його молекули.

Насіння соняшника гібриду Світоч і сорту Флагман замочували розчинами препаратів у чашках Петрі на фільтрувальному папері розчинами препаратів - гіберелової кислоти $\left(Г К_{3}\right.$, 150 мг/л), трептолему (0,033 мл/л), хлормекватхлориду (ССС, $1 \%$ водний розчин) і паклобутразолу $(0,05 \%$ водний розчин) $\mathrm{i}$ пророщували за $20{ }^{\circ} \mathrm{C}$ у термостаті. Контрольний варіант пророщували на дистильованій воді. Біологічна повторність досліджень п'ятиразова. На третю добу пророщування визначали енергію проростання. Оскільки інтенсивний гідроліз олії в насінні соняшнику відбувається з шостої по дванадцяту добу, на шосту добу проростки фіксували за $105^{\circ} \mathrm{C}$ та досушували за $65{ }^{\circ} \mathrm{C}$ до повітряно-сухого стану для наступного аналізу вмісту олії та кількісного аналізу вмісту вищих жирних кислот у ній. У проростаючому насінні соняшнику на шосту добу визначали активність кислих і лужних ліпаз методом титрування. Для створення слабкого кислого середовища використовували ацетатний буфер із $\mathrm{pH}$ 4,7, а для створення лужного середовища - боратний буфер із $\mathrm{pH} 8,5$. Для оцінювання можливої присутності крохмалю проводили якісну реакцію з реактивом Люголя. Загальний вміст олії в насінні визначали методом екстракції в апараті Сокслета, як органічний розчинник використовували петролейний ефір із температурою кипіння 40- $65^{\circ} \mathrm{C}$. У зразках виділеної олії визначали ії якісні характеристики: кислотне число, число омилення, ефірне число (АОАС, 2010). Аналітична повторність досліджень - п’ятиразова.

Вміст і якісний склад вищих жирних кислот (ВЖК) визначали методом газової хроматографії на хроматографі «Кристал-2000» фірми Хроматек (Росія). Умови хроматографування: скляні колонки розміром $1500 \times 2$ мм, заповнені сорбентом інтертоп-супер $+5 \%$ неоплекс 400 , зернистість сорбенту 0,16 0,20 мм. Газ-носій - азот, швидкість проходження газу 70 мл/хв. Температура колонки $-200{ }^{\circ} \mathrm{C}$, випаровувача $-230^{\circ} \mathrm{C}$, полум'яно-іонізаційного детектора $-240^{\circ} \mathrm{C}$.

Результати досліджень обробляли статистично за допомогою комп’ютерної програми Statistica 6.0 (StatSoft Inc., USA). У таблицях і на рисунках наведено середньоарифметичні значення та їх стандартні похибки.

\section{Результати}

Пізнання механізмів утилізації резервних ліпідів важливе для розуміння функціонування донорно-акцепторної системи рослин у гетеротрофний період розвитку, оскільки саме ліпіди відкладаються як основна резервна речовина насіння у 75\% видів квіткових рослин. Гідроліз резервних ліпідів здійснюється за впливу ліпаз (КФ 3.1.1.3), які розщеплюють триацилгліцериди на гліцерин та вищі жирні кислоти. Ці продукти гідролізу можуть перетворюватися на глюкозу у процесах глюконеогенезу, внаслідок чого забезпечуються процеси органота гістогенезу проростків. Різне напруження донорно-акцепторних відносин між зоною депонування резервних сполук і зоною росту проростка створювали в експерименті, використовуючи стимулятори росту (гіберелова кислота, трептолем) та інгібітори росту ретарданти хлормекватхлорид і паклобутразол, що спричинило зміни швидкості проростання насіння та, відповідно, використання різної кількості основної резервної речовини. Результати дослідження свідчать, що застосування гіберелової кислоти, синтетичного стимулятора росту трептолему та інгібіторів росту хлормекватхлориду та паклобутразолу викликало зміни ліпідного обміну проростків та швидкості їх проростання (табл. 1). На третю добу пророщування насіння енергія проростання за дії гібереліну та трептолему достовірно не відрізнялася від контролю. Разом із цим, застосування інгібіторів росту хлормекватхлориду та паклобутразолу в обох сортів соняшнику викликало суттєве її зниження.

\section{Таблиця 1}

Дія стимуляторів росту та ретардантів на інтенсивність проростання, вміст і якісні характеристики олії у проростках соняшнику ( $\mathrm{n}=5)$

\begin{tabular}{|c|c|c|c|c|c|}
\hline Об'єкт & Варіант досліду & $\begin{array}{c}\text { Енергія } \\
\text { проростання, \% }\end{array}$ & $\begin{array}{l}\text { Вміст олії, \% на масу } \\
\text { сухої речовини }\end{array}$ & $\begin{array}{c}\text { Активність кислих } \\
\text { ліпаз, мл 0,1 N NaOH/Г }\end{array}$ & $\begin{array}{c}\text { Активність лужних ліпаз, } \\
\text { мл 0,1 N NaOH/г }\end{array}$ \\
\hline \multirow{3}{*}{ Сорт Флагман } & контроль & $74,0 \pm 1,4$ & $48,5 \pm 0,5$ & $2,3 \pm 0,1$ & $3,6 \pm 0,2$ \\
\hline & трептолем & $75,3 \pm 3,4$ & $46,2 \pm 1,5$ & $3,9 \pm 0,2^{*}$ & $4,0 \pm 0,2$ \\
\hline & $\mathrm{CCC}$ & $60,7 \pm 2,2 *$ & $49,1 \pm 0,6$ & $1,0 \pm 0,1^{*}$ & $2,1 \pm 0,1^{*}$ \\
\hline \multirow{3}{*}{ Гібрид Світоч } & контроль & $99,4 \pm 1,3$ & $43,2 \pm 0,5$ & $1,8 \pm 0,1$ & $1,9 \pm 0,1$ \\
\hline & $\Gamma K$ & $99,8 \pm 1,1$ & $42,9 \pm 0,4$ & $1,9 \pm 0,2$ & $2,1 \pm 0,1$ \\
\hline & $\mathrm{P}_{333}$ & $93,6 \pm 1,2^{*}$ & $47,9 \pm 0,3^{*}$ & $1,3 \pm 0,1^{*}$ & $1,5 \pm 0,1^{*}$ \\
\hline
\end{tabular}

Примітка: * - різниця достовірна за $\mathrm{P}<0,05$.

Аналіз вмісту олії у проростках на шостий день пророщування насіння по варіантах досліду свідчить про значне його зменшення в контролі, за впливу застосованих стимуляторів росту, i вищий вміст олії за дії хлормекватхлориду та паклобутразолу. Це показник уповільнення утилізації резервних ліпідів під час проростання насіння за дії ретардантів. Використання резервної олії у період проростання насіння олійних культур відбувається за участі ліпаз. Ліпази синтезуються на мембранах ендоплазматичного ретикулюму та переносяться у вигляді секреторних пухирців до сферосом сім'ядоль, де після руйнування мембрани кисла ліпаза розщеплює тригліцериди до гліцерину та вищих жирних кислот. 3 іншого боку загальновідомо, що розщеплення ліпідів може відбуватися за впливу лужних ліпаз у гліоксісомах. Аналіз активності кислих і лужних ліпаз по варіантах досліду свідчить про вищу їх активність за дії гіберелової кислоти та трептолему, та зниження активності цих ферментів за впливу обох ретардантів (рис. 1). Привертає увагу той факт, що інтенсивність проростання у контролі та у процесі застосування стимуляторів росту достовірно не відрізнялася. На нашу думку, це свідчить про достатнє забезпечення процесу проростання насіння соняшнику синтезованими ендогенними гіберелінами, у зв'язку з чим додаткове застосування екзогенних стимуляторів мало впливало на процес. Аналогічна ситуація відмічалася для вмісту резервної олії по цих варіантах досліду - різниця була мінімальною. Разом із тим, застосування ретардантів четвертинної аміачної солі хлормекватхлориду та триазолпохідного препарату паклобутразолу викликало блокування синтезу ендогенних гіберелінів, що, на нашу думку, спричинило уповільнення процесу проростання та використання резервних 
ліпідів. Відомо, що і четвертинні амонієві сполуки, і триазолпохідні препарати інгібують синтез гіберелінів, причому чим більше ланок біосинтезу гіберелінів вони блокують, тим вища їх активність. Так, четвертинні амонієві сполуки (ССС, фосфон Д, АМО1618) інгібують активність ент-каурен-синтази під час утворення копалілпірофосфату з геранілгераніолдифосфату, а паклобутразол перериває синтез гібереліну зразу у трьох точках, із чим пов'язана його вища активність (Kuryata, 2009).

Застосування гістохімічної реакції з реактивом Люголя на крохмаль свідчило про відсутність цього полісахариду в проростаючому насінні. Отже, для культури соняшнику посилення проростання не супроводжується синтезом амілаз de поvo, що характерно для злакових культур. Дозрівання та проростання насіння олійних культур супроводжуються суттєвими якісними змінами складу вищих жирних кислот, хоча послідовність їх перетворення під час проростання насіння залишається значною мірою невідомою. Аналіз низки якісних характеристик олії, виділеної з насіння на 6-ту добу проростання по варіантах досліду, дає можливість оцінити загальну спрямованість процесів, які супроводжують проростання насіння соняшнику. Зокрема, за дії ГК і і різних типів ретардантів відбувалися зміни кислотного, лужного та ефірного чисел олії порівняно з контролем (табл. 2).

\section{Таблиця 2}

Дія $Г K_{3}$ і паклобутразолу на якісні характеристики олії насіння соняшнику гібриду Світоч (6-а доба проростання, $\mathrm{n}=5$ )

\begin{tabular}{lrrc}
\multicolumn{1}{c}{ Показник } & Контроль & $\begin{array}{c}\text { ГК } \\
150 \mathrm{Mг} / л\end{array}$ & $\begin{array}{c}\text { Паклобутразол, } \\
0,05 \%\end{array}$ \\
\hline $\begin{array}{l}\text { Кислотне число, } \\
\text { мг КОН/г олії }\end{array}$ & $4,1 \pm 0,2$ & $3,9 \pm 0,1$ & $3,6 \pm 0,2$ \\
$\begin{array}{l}\text { Число омилення, } \\
\text { мг КОН/г олії }\end{array}$ & $172,2 \pm 7,0$ & $189,7 \pm 4,2^{*}$ & $177,3 \pm 5,1$ \\
$\begin{array}{l}\text { Ефірне число, } \\
\text { мг КОН/г олії }\end{array}$ & $168,1 \pm 6,8$ & $185,8 \pm 4,1^{*}$ & $173,7 \pm 4,9$ \\
$\begin{array}{l}\text { Йодне число, } \\
\text { г І/100 г олії }\end{array}$ & $118,3 \pm 1,3$ & $128,6 \pm 2,4^{*}$ & $121,5 \pm 2,1$ \\
\hline
\end{tabular}

Примітка: *-різниця достовірна за $\mathrm{P}<0,05$.

Кислотне число характеризує кількість вільних вищих жирних кислот в олії. Отримані дані свідчать, що за впливу ретарданту паклобутразолу вміст вільних жирних кислот в олії був меншим, ніж у варіанті з ГК зробити висновок про повільніший гідроліз олії запасних тканин насіння за дії цього рістінгібувального препарату.

Число омилення найбільше саме у варіанті із застосуванням гіберелової кислоти, а вище значення ефірного числа в олії за дії ГК ${ }_{3}$ свідчить, очевидно, про уповільнене використання гліцерину на утворення цукрів у проростаючому насінні на перших етапах розвитку, ніж використання для цього жирних кислот.

Показник вмісту ненасичених ВЖК в олії - йодне число. За дії препаратів відбуваються зміни цього показника: на 6-ту добу проростання йодне число зростає у варіантах із застосуванням як гіберелової кислоти, так паклобутразолу, що свідчить про відповідне підвищення вмісту ненасичених ВЖК в олії.

Повніше уявлення про особливості складу соняшникової олії за дії препаратів може дати хроматографічне дослідження iii жирнокислотного складу. Застосування ретардантів у період бутонізації спричиняє зміни профілю жирних кислот і співвідношення ненасичених і насичених жирних кислот у насінні олійних культур. Зокрема, відмічено збільшення у соняшниковій, ріпаковій, соєвій, лляній оліях зазначеного співвідношення за дії ретардантів, що корелює зі збільшенням показників йодного числа. У сої це співвідношення змінюється через збільшення вмісту незамінної лінолевої та зменшення пальмітинової та стеаринової кислот. У рослин соняшнику - те ж за рахунок лінолевої кислоти (Kuryata and Poprotska, 2016).

У рослин льону олійного за дії хлормекватхлориду достовірно зростав вміст олеїнової та ліноленової кислот (Kuryata and Khodanitska, 2012). Разом із цим, у рослин маку олійного вміст насичених і ненасичених жирних кислот не змінюється
(Kuryata and Polyvanyi, 2015). Одне 3 важливих практичних завдань - зменшення в олії вмісту ліноленової кислоти, яка під час зберігання надає їй гіркого смаку. Ретарданти викликали зменшення вмісту цієї кислоти в ріпаковій олії, яке супроводжувалося, як правило, зростанням вмісту лінолевої кислоти (Kuryata and Poprotska, 2016). Питання утилізації ВЖК на потреби формування проростка в гетеротрофну фазу розвитку вивчені значно менше.

У зразках соняшникової олії насіння сорту Світоч на шосту добу проростання присутні 9 вищих жирних кислот: міристинова, стеаринова, пальмітинова, пальмітолеїнова, олеїнова, лінолева, ліноленова, арахінова та бегенова. Серед ненасичених ВЖК домінували олеїнова та лінолева кислоти, серед насичених - пальмітинова кислота. Застосування гіберелової кислоти та паклобутразолу зумовило зміни вмісту цих кислот в олії (табл. 3).

\section{Таблиця 3}

Вплив гіберелової кислоти та паклобутразолу на жирнокислотний складі олії насіння сорту Світоч під час проростання (\% на сиру речовину, $\mathrm{n}=5$ )

\begin{tabular}{lccc}
\hline \multicolumn{1}{c}{ Назва кислоти } & Контроль & $\begin{array}{c}\text { Гіберелова } \\
\text { кислота }\end{array}$ & Паклобутразол \\
\hline Міристинова & $0,25 \pm 0,002$ & $0,16 \pm 0,001^{*}$ & $0,15 \pm 0,002^{*}$ \\
Стеаринова & $4,05 \pm 0,06$ & $4,41 \pm 0,04^{*}$ & $4,02 \pm 0,05^{*}$ \\
Пальмітинова & $7,15 \pm 0,10$ & $5,94 \pm 0,15^{*}$ & $6,77 \pm 0,11^{*}$ \\
Пальмітолеїнова & $0,05 \pm 0,001$ & $0,04 \pm 0,001^{*}$ & $0,05 \pm 0,002$ \\
Олеїнова & $35,18 \pm 0,15$ & $35,69 \pm 0,11^{*}$ & $34,29 \pm 0,06^{*}$ \\
Лінолева & $52,55 \pm 0,25$ & $52,19 \pm 0,09$ & $53,17 \pm 0,06^{*}$ \\
Ліноленова & $0,36 \pm 0,005$ & $1,13 \pm 0,002^{*}$ & $1,16 \pm 0,004^{*}$ \\
Арахінова & $0,20 \pm 0,003$ & $0,22 \pm 0,005^{*}$ & $0,19 \pm 0,005$ \\
Бегенова & $0,21 \pm 0,002$ & $0,22 \pm 0,001^{*}$ & $0,20 \pm 0,002^{*}$ \\
Сума ненасичених кислот & 88,1 & 89,1 & 88,7 \\
Сума насичених кислот & 11,9 & 10,9 & 11,3 \\
Співвідношення ненаси- & 7,4 & 8,1 & 7,8 \\
чені / насичені кислоти & & & \\
\hline
\end{tabular}

Примітка: * - різниця достовірна за $\mathrm{P}<0,05$.

За дії гібереліну зростав, а за дії паклобутразолу зменшувався вміст олеїнової кислоти проти контролю та протилежні зміни відмічалися для лінолевої кислоти. Суттєве зростання вмісту ненасиченої ліноленової кислоти відбувалося також в обох варіантах досліду проти контролю. Відповідно змінювалося співвідношення ненасичені / насичені ВЖК у процесі проростання за дії препаратів. В обох варіантах досліду відбувалося підвищення цього показника. Отже, застосування екзогенного гібереліну та антигіберелінового препарату паклобутразолу викливає суттєві зміни у використанні резервної олії та її жирнокислотного складу у період проростання насіння соняшнику.

\section{Обговорення}

Застосування регуляторів росту з протилежним механізмом дії для створення різного напруження донорно-акцепторних відносин у рослині дозволяє проаналізувати особливості перерозподілу асимілятів і депонованих в органах запасу резервних речовин на різних етапах онтогенезу. Такий підхід у першу чергу дозволяе штучно перерозподіляти потоки продуктів фотосинтезу до господарсько-цінних органів, тобто оптимізувати продукційний процес рослин сільськогосподарських культур (Kuriata et al., 2016). Застосування ретардантів дозволяє також забезпечити зберігання продукції. Зокрема, обробка бульб картоплі паклобутразолом, хлормекватхлоридом суттєво гальмує проростання, що сприяє збереженню продукції (Rogach et al., 2016).

Застосування цього підходу у гетеротрофну фазу розвитку (у період проростання) дозволяє визначити ефективність використання запасних речовин у насінні з різним типом резервних сполук (крохмалю, білків та олії) встановити можливі регуляторні механізми цього процесу. Існує тісний зв'язок між змінами ростових характеристик за дії ретардантів і активністю гіберелінів. Зокрема, за впливу паклобутразолу, хлормекватхлориду та декстрелу відмічено значне зменшення активності вільних гіберелінів 
у пагонах малини в умовах вегетаційного та польового дослідів, у той час як уведення екзогенної гіберелової кислоти суттєво підвищувало їх активність у тканинах стебла (Kuryata, 2009). Раніше нами було встановлено, що ріст проростків гарбуза пригнічувався на світлі, однак обробка проростків гібереловою кислотою значно знімала ефект, викликаний світлом.

У разі зменшення синтезу гібереліну за впливу ретарданту рістгальмівний ефект світла посилювався, що свідчить про те, що гібереліни - активні модифікатори фоторецепторної системи рослин (Poprotska and Kuryata, 2017). Формування проростками «запиту» на резервні асиміляти із сім'ядоль великою мірою визначається зміною активності субапікальних меристем, що проявляється у прискоренні проростання насіння, посиленні гістогенезу за дії гібереліну та послаблення цих процесів за дії ретарданту. Отримані результати щодо визначення вмісту різних форм азоту та олії в сім’ядолях гарбуза свідчать, що гібереліни - важлива ланка унікального регуляторного механізму мобілізації резервних речовин у насінні, яке проростає, незалежно від їх хімічної природи (Kuryata and Poprotska, 2016).

Особливості утилізації резервної олії, вищих жирних кислот за умов прискорення або уповільнення проростання насіння олійних культур за дії гібереліну та антигіберелінових препаратів потребують поглибленого вивчення. Отримані результати свідчать, що насіння соняшнику під час проростання достатньо забезпечене ендогенними гіберелінами, внаслідок чого додаткова обробка його гібереловою кислотою та трептолемом не спричиняла суттєвого прискорення проростання. Утилізація резервної олії в контролі та за дії стимуляторів росту відбувалася суттєво інтенсивніше, ніж у варіантах із застосуванням ретардантів хлормекватхлориду та паклобутразолу. На нашу думку, інгібування проростання та використання резервної олії на процеси морфогенезу за дії ретардантів визначалася саме блокуванням ними синтезу ендогенних гіберелінів. Дефіцит гормону спричинив зменшення гідролітичної активності резервних тканин внаслідок інгібування синтезу ліпаз і активності меристем проростків, тобто обмежувалася активність як донорної, так і акцепторної сфери рослини.

Отримані результати свідчать, що різниця в умісті олії в період проростання насіння за дії стимуляторів росту та контролю була меншою, ніж за дії ретардантів. Аналогічну закономірність спостерігалися під час вивчення проростання насіння гарбуза за дії гібереліну та хлормекватхлориду. Пояснення цьому факту полягає в тому, що у період проростання використовуються також інші сполуки, у першу чергу резервні азотумісні речовини (Poprotska and Kuryata, 2017). Проростання насіння гарбуза супроводжується не лише використанням резервної олії та азотумістних сполук, а й суттєвою перебудовою полісахаридного комплексу клітинних стінок. При цьому можливе використання як резервної речовини пентозанів клітинних стінок, відбувається зміна конформації та часткове збільшення молекулярної маси пектинів. Процес посилюється під час скотоморфогенезу внаслідок інтенсивного росту проростків за відсутності автотрофного живлення та, як наслідок, глибшої утилізації резервів донора пластичних речовин сім’ядоль (Poprotska, 2014).

Результати свідчать, що за дії антигіберелінового препарату паклобутразолу змінюються якісні показники олії: зменшується кислотне число, число омилення та ефірне число порівняно із застосуванням гіберелової кислоти. На нашу думку, це - свідчення того, що інгібування синтезу гіберелінів за дії ретарданту викликає зменшення загальної кількості вільних ВЖК в олії, уповільнення процесів їх окиснення та інтенсивніший глюконеогенез гліцерину. Підвищення вмісту ненасичених жирних кислот в олії проростаючого насіння за дії гіберелової кислоти та паклобутразолу порівняно 3 контролем можна пояснити різною інтенсивністю використання окремих кислот на процеси морфогенезу та процеси десатурації. На нашу думку, зростання частки ненасичених ВЖК в олії проростка за дії гіберелової кислоти може відбуватися за рахунок часткової десатурації насичених кислот. На таку можливість збілышення вмісту ненасичених жирних кислот в олії вказує Bezdudnaya (2005) під час вивчення змін жирно- кислотного складу олії у процесі проростання насіння сої. Вищий вміст ненасичених ВЖК в олії проростків соняшнику за дії паклобутразолу можливо пояснити уповільненням використання ненасичених кислот у процесах морфогенезу, оскільки вміст олії у проростках цього варіанта значно вищий (табл. 1), ніж у контролі та варіанті із застосуванням гіберелової кислоти.

\section{Висновки}

Застосування стимуляторів росту та антигіберелінових препаратів (ретардантів) - ефективний прийом штучної реконструкції донорно-акцепторних відносин у період проростання насіння олійних культур, що дозволяє встановити роль гормонального фактора в утилізації резервних ліпідів у гетеротрофну фазу розвитку рослини. Встановлено відсутність резервного крохмалю під час проростання насіння соняшнику. Блокування синтезу гіберелінів ретардантами спричинило зниження активності кислих і лужних ліпаз, уповільнення гідролізу резервної олії, суттєвих змін кислотного числа та числа омилення, йодного числа в олії під час проростання, зниження активності меристем і відповідне зниження енергії проростання насіння. Дія гіберелової кислоти та трептолему протилежна. У зразках соняшникової олії насіння сорту Світоч на шосту добу проростання присутні дев'ять вищих жирних кислот (міристинова, стеаринова, пальмітинова, пальмітолеїнова, олеїновіа, лінолева, ліноленова, арахінова та бегенова). За дії гібереліну зростав, а за дії паклобутразолу зменшувався вміст олеїнової кислоти проти контролю та протилежні зміни відмічалися для лінолевої кислоти. Суттєве зростання вмісту ненасиченої ліноленової кислоти відбувалося в обох варіантах досліду проти контролю. Гіберелова кислота стимулювала, а ретардант паклобутразол уповільнював використання вільних вищих жирних кислот на процеси морфогенезу.

\section{References}

AOAC (2010). Official methods of analysis of association of analytical chemist international. 18th ed. Rev. 3.2010. Asso. of Analytical Chemist. Gaithersburg, Maryland, USA.

Bezdudnaya, E. F. (2005). Dinamika lipidov v semenah i prorostkah soi pri prorastanii [Lipid dynamics in soya seeds and seedlings during germinating]. Visnyk Kharkivskogo Natsionalnogo Universytetu imeni V. N. Karazina. Seriya: Biologiya, 709, 22-27 (in Russian).

Bonelli, L. E., Monzon, J. P., Cerrudo, A., \& Rizzalli, R. H., Andrade, F. H. (2016). Maize grain yield components and source-sink relationship as affected by the delay in sowing date. Field Crops Research, 198, 215-225.

De Wit, M., \& Pierik, R. (2016). Photomorphogenesis and Photoreceptors. Canopy Photosynthesis: From Basics to Applications, 42, 171-186.

Franklin, K. A. (2016). Photomorphogenesis: Plants feel blue in the shade. Current Biology, 26(24), R1275-R1276.

Golovatskaya, I. F., \& Karnachuk, R. A. (2007). Dinamika rosta rastenij i soderzhanie endogennyh fitogormonov v processe skoto- $i$ fotomorfogeneza fasoli [Dynamics of growth and the content of endogenous phytohormones during kidney bean scoto- and photomorphogenesis]. Fiziologija Rastenij, 54(3), 461-468 (in Russian).

Grytsayenko, Z. M., Ponomarenko, S. P., Karpenko, V. P., \& Leontiuk, I. B. (2008). Biologichno aktyvni rechovyny $\mathrm{V}$ roslynnyctvi [Biologically active substances in plant growth]. NICHLAVA, Kyiv (in Ukrainian).

Hedden, P., \& Thomas, S. G. (2016). Annual Plant Reviews. Vol. 49. The Gibberellins. John Wiley \& Sons.

Hornitschek, P., Kohnen, M. V., Lorrain, S., Rougemont, J., Ljung, K., LópezVidriero, I., Franco-Zorrilla, J. M., Solano, R., Trevisan, M., Pradervand, S., Xenarios, I., \& Fankhauser, C. (2012). Phytochrome interacting factors 4 and 5 control seedling growth in changing light conditions by directly controlling auxin signaling. The Plant Journal, 71(5), 699-711.

Humplík, J. F., Turečková, V., Fellner, M., \& Bergougnoux, V. (2015). Spatiotemporal changes in endogenous abscisic acid contents during etiolated growth and photomorphogenesis in tomato seedlings. Plant Signaling and Behavior, 10(8), e1039213.

Kumar, S., Sreenivas, G., Satyanarayana, J., \& Guha, A. (2012). Paclobutrazol treatment as a potential strategy for higher seed and oil yield in field-grown Camelina sativa L. Crantz. BSK Research Notes 5(1), 13.

Kuriata, V. G., Rohach, V. V., Rohach, T. I., \& Khranovska, T. V. (2016). The use of antigibberelins with different mechanisms of action on morphogenesis and 
production process regulation in the plant Solanum melongena (Solanaceae) Visnyk of Dnipropetrovsk University. Biology, Ecology, 24(1), 230-234.

Kuryata, V. G., \& Khodanitska, O. O. (2012) Osoblyvosti morfogenezu produkcijnogo procesu l'onu-kucherjavcju za dii' hlormekvathlorydu i treptolemu [Peculiarities of morphogenesis and production process of Linum usitatissimum var. humile (Mill.) Pers. plants under the effect of chlormequatchloride and treptolem]. Fiziologiya i Biohimiya Kul'turnikh Rasteniy, 44(6), 522-528 (in Ukrainian).

Kuryata, V. G., \& Polyvanyi, S. V. (2015). Potuzhnist’ fotosyntetychnogo aparatu ta nasinnyeva produktyvnist' maku oliynogo za dii' retardantu folikuru [Effect of retardant folicur on photosynthetic apparatus and seed productivity of oil poppy]. Fiziologiya Rasteniy i Genetika, 47(4), 313-320 (in Ukrainian).

Kuryata, V. G., \& Poprotska, I. V. (2016). Fiziologichni osnovy zastosuvannja retardantiv na olijnyh kul'turah [The physiological basics of application of retardants to oilseeds]. Fiziologiya Rasteniy i Genetika, 48(6), 475-487 (in Ukrainian).

Kutschera, U., \& Briggs, W. R. (2013). Seedling development in buckwheat and the discovery of the photomorphogenic shade-avoidance response. Plant Biology, 15(6), 931-940.

Ljung, K., Nemhauser, J. L., \& Perata, P. (2015). New mechanistic links between sugar and hormone signalling networks. Current Opinion in Plant Biology, 25, 130-137.

Matysiak, K., \& Kaczmarek, S. (2013). Effect of chlorocholine chloride and triazoles - tebuconazole and flusilazole on winter oilseed rape (Brassica napus var. oleifera L.) in response to the application term and sowing density. Journal of Plant Protection Resesrch, 53(1), 79-88.

Minguet, E. G., Alabadi, D., \& Blázquez, M. A. (2014). Gibberellin implication in plant growth and stress responses. Phytohormones: A Window to Metabolism, Signaling and Biotechnological Applications, 119-161.

Mohammad, N. K., \& Mohammad, F. (2013). Effect of $\mathrm{GA}_{3}$, N and P ameliorate growth, seed and fibre yield by enhancing photosynthetic capacity and carbonic anhydrase activity of linseed. Integrative Agriculture, 12(7), 1183-1194.

Panyapruek, S., Sinsiri, W., Sinsiri, N., Arimatsu, P., \& Polthanee, A. (2016). Effect of paclobutrazol growth regulator on tuber production and starch quality of cassava (Manihot esculenta Crantz). Asian Joumal of Plant Sciences, 15, 1-7.

Pavlista, A. D. (2013). Influence of foliar-applied growth retardants on russet burbank potato tuber production. American Journal of Potato Research, 90(4), 395- 401 .

Pobudkiewicz, A. (2014). Influence of growth retardant on growth and development of Euphorbia pulcherrima Willd. ex Klotzsch. Acta Agrobotanica, 67(3), 65-74.

Poprotska, I. V., \& Kuryata, V. G. (2017). Features of gas exchange and use of reserve substances in pumpkin seedlings in conditions of skoto- and photomorphogenesis under the influence of gibberellin and chlormequatchloride. Regulatory Mechanisms in Biosystems, 8(1), 71-76.

Poprotska, I. V. (2014). Zminy v polisaharydnomu kompleksi klitynnyh stinok sim'yadolej prorostkiv garbuza za riznoyi napruzhenosti donorno-aktseptornyh vidnosyn $\mathrm{v}$ protsesi prorostannya [Changes in polysaccharide complex of cell walls of the pumpkin seedlings cotyledons under different level of source-sink relations during germination]. Fiziologiya i Biohimiya Kulturnykh Rastenij, 46(3), 190-195 (in Ukrainian).

Ramburan, S., \& Greenfield, P. L. (2007). Use of ethephon and chlormequat chloride to manage plant height and lodging of irrigatend barley (cV. Puma) when hight rates of $\mathrm{N}$-fertiliser are applied. South African Journal of Plant and Soil, 24(4), 181-187.
Rogach, V. V., \& Rogach, T. I. (2015). Vplyv syntetychnyh stymulyatoriv rostu na morfofiziologichni harakterystyky ta biologichnu produktyvnist' kul'tury kartopli [Influence of synthetic growth stimulators on morphological and physiological characteristics and biological productivity of potato culture]. Visnyk of Dnipropetrovsk University. Biology, Ecology, 23(2), 221-224 (in Ukrainian).

Rogach, V. V., Poprotska, I. V., \& Kuryata, V. G. (2016). Diya giberelinu ta retardantiv na morfogenez, fotosyntetychnyj aparat i produktyvnist' kartopli [Effect of gibberellin and retardants on morphogenesis, photosynthetic apparatus and productivity of the potato]. Visnyk of Dnipropetrovsk University. Biology, Ecology, 24(2), 416-419 (in Ukrainian).

Sang-Kuk, K., \& Hak-Yoon, K. (2014). Effects of gibberellin biosynthetic inhibitors on oil, secoisolaresonolodiglucoside, seed yield and endogenous gibberellin content in flax. Korean Journal of Plant Resources, 27(3), 229-235.

Sardoei, A. S., Yazdi, M. R., \& Shshdadneghad, M. (2014). Effect of cycocel on growth retardant cycocel on reducing sugar, malondialdehyde and other aldehydes of Cannabis sativa L. International Journal of Biosciences, 4(6), 127-133.

Savage, J. A., Haines, D. F., \& Holbrook, N. M. (2015). The making of giant pumpkins: How selective breeding changed the phloem of Cucurbita maxima from source to sink. Plant, Cell and Environment, 38(8), 1543-1554.

Sugiura, D., Sawakami, K., Kojim, M., Sakakibara, H., Terashima, I., \& Tateno, M. (2015). Roles of gibberellins and cytokinins in regulation of morphological and physiological traits in Polygonum cuspidatum responding to light and nitrogen availabilities. Functional Plant Biology, 42(4), 397-409.

Tae-Yun, K., \& Jung-Hee, H. (2012). Effects of hexaconazole on growth and antioxidant potential of cucumber seedlings under UV-B radiation. Environmental Sciences, 21(12), 1435-1447.

VanHook, A. M. (2016). Rapidly inhibiting ethylene signaling with light. Science Signaling, 9(458), ec294.

Wang, Y., Gu, W., Xie, T., Li, L., Sun, Y., Zhang, H., Li, J., \& Wei, S (2016). Mixed compound of DCPTA and CCC increases maize yield by improving plant morphology and upregulating photosynthetic capacity and antioxidants. PLoS ONE, 11(2), e0149404.

Wu, S.-H. (2014). Gene expression regulation in photomorphogenesis from the perspective of the central dogma. Annual Review of Plant Biology, 65, 311-333.

Yan, W., Yanhong, Y., Wenyu, Y., Taiwen, Y., Weiguo, L., \& Wang, X. (2013). Responses of root growth and nitrogen transfer metabolism to uniconazole, a growth retardant, during the seedling stage of soybean under relay strip. Communications in Soil Science and Plant Analysis Intercropping System, 44(22), 3267-3280

Yan, Y., Wan, Y., Liu, W., Wang, X., Yong, T., \& Yang, W. (2015). Influence of seed treatment with uniconazole powder on soybean growth, photosynthesis, dry matter accumulation after flowering and yield in relay strip intercropping system. Plant Production Science, 18(3), 295-301.

Yu, S. M., Lo, S. F., \& Ho, T. D. (2015). Source-sink communication: Regulated by hormone, nutrient, and stress cross-signaling. Trends in Plant Science, 20(12), 844-857.

Zhang, D, Jing, Y., Jiang, Z., \& Lin, R. (2014). The chromatin-remodeling factor PICKLE integrates brassinosteroid and gibberellin signaling during skotomorphogenic growth in Arabidopsis. The Plant Cell, 26(6), 2472-2485.

Zhang, W., Xu, F., Hua, C., \& Cheng, S. (2013). Effect of chlorocholine chloride on chlorophyll, photosynthesis, soluble sugar and flavonoids of Ginkgo biloba. Notulae Botanicae Horti Agrobotanici Cluj-Napoca, 41(1), 97-103. 